\title{
Pedobacter cryoconitis sp. nov., a facultative psychrophile from alpine glacier cryoconite
}

\author{
Rosa Margesin, ${ }^{1}$ Cathrin Spröer, ${ }^{2}$ Peter Schumann ${ }^{2}$ and Franz Schinner ${ }^{1}$ \\ ${ }^{1}$ Institut für Mikrobiologie, Universität Innsbruck, Technikerstrasse 25, A-6020 Innsbruck, \\ Austria \\ ${ }^{2}$ Deutsche Sammlung für Mikroorganismen und Zellkulturen, Mascheroder Weg 1b, D-38124 \\ Braunschweig, Germany
}

Rosa Margesin

rosa.margesin@uibk.ac.at

Cold-adapted micro-organisms, able to proliferate in cold environments, and their enzymes provide a large biotechnological potential, offering numerous economic and ecological advantages (Gerday et al., 2000; Margesin et al. 2002a). A wide range of metabolic activities has been detected at low temperatures, including degradation of natural and xenobiotic organic compounds such as protein, cellulose, carbohydrates, lignin and aliphatic and aromatic hydrocarbons (Morita et al., 1997; Huston et al., 2000; Margesin et al., 2002b). Micro-organisms able to degrade oil hydrocarbons at low temperatures are useful for the bioremediation of contaminated cold environments (Bej et al., 2000; Margesin \& Schinner, 2001; Yumoto et al., 2002).

Adaptation strategies with regard to growth, enzyme production and enzyme activity enable cold-adapted microorganisms to compensate for the negative effects of low temperatures on biochemical reactions. These organisms can be isolated from permanently cold environments such as fresh and marine waters, snow, glacier and sea ice, polar and high-alpine soils, cold deserts and permafrost soils. An ideal habitat is cryoconite on glacier ice (Takeuchi et al., 2001; Margesin et al., 2002b), a dark mixture on the surface and in microcaverns of glaciers, consisting predominantly of

Published online ahead of print on 21 February 2003 as DOI 10.1099/ ijs.0.02436-0.

The GenBank/EMBL/DDBJ accession number for the 16S rDNA sequence of strain $A 37^{\top}$ is $A J 438170$. organic debris (micro-organisms, pollen, plant and animal litter) and inorganic dust. Little is known of the microbial life in alpine cryoconite.

We isolated a facultatively psychrophilic representative of the genus Pedobacter from alpine glacier cryoconite and report the results of a phenotypic, genetic and phylogenetic examination. The strain degrades diesel oil and produces high yields of protease at low temperatures. The data obtained suggest that the isolate represents a novel species of the genus Pedobacter, and the name Pedobacter cryoconitis sp. nov. is proposed.

Cryoconite samples were collected in a ski area on the Stubaier Glacier in the Tyrolean Alps (Austria) at an altitude of $3000 \mathrm{~m}$ above sea level and microbial strains were isolated as described by Margesin et al. (2002b). Morphological and phenotypic properties of the strain were investigated by using standard procedures (Süßmuth et al., 1987). Aminopeptidase activity (Bactident; Merck) was tested to confirm classical Gram-staining. The biochemical profile was determined with API 20NE strips (bioMérieux) incubated at 10 and $20^{\circ} \mathrm{C}$ for up to 4 days. Carbon assimilation was tested by using API $50 \mathrm{CH}$ strips (bioMérieux) incubated at $20^{\circ} \mathrm{C}$ for up to 5 days. Sensitivity to antibiotics was determined with ATB G- and ATB G + strips (bioMérieux) at 10 and $20^{\circ} \mathrm{C}$. Amylase, protease, lipase and $\beta$-lactamase activities were tested on nutrient broth agar plates supplemented with starch or skimmed milk ( $2 \mathrm{~g}$ each compound $\mathrm{l}^{-1}$ ), tributyrin $\left(5 \mathrm{ml} \mathrm{l}^{-1}\right)$ or ampicillin $\left(50 \mathrm{mg}^{-1}\right)$. After $24-48 \mathrm{~h}$ at 
Table 1. Phenotypic features that distinguish Pedobacter cryoconitis sp. nov. from other Pedobacter species

Data were taken from Steyn et al. (1998) and this study. +, Positive; -, negative; (+); weak reaction; V, variable; ND, no data available. All strains are positive for aerobic growth, production of a yellow pigment on nutrient agar, presence of catalase, oxidase and $\beta$-galactosidase and assimilation of D-glucose, D-mannose, lactose and melezitose. All strains are negative for Gram stain, motility (non-flagellated), sporulation, indole production, $\mathrm{H}_{2} \mathrm{~S}$ production from thiosulfate, nitrate reduction, presence of urease, arginine dihydrolase and tryptophan deaminase, assimilation of erythritol, L-xylose, methyl $\beta$-xyloside, L-sorbose, dulcitol, inositol, xylitol, D-tagatose, D-fucose, L-arabitol, gluconate, caprate, adipate, phenylacetate, D-lyxose, D-arabitol, 5-ketogluconate, malate and citrate and growth on MacConkey agar. All strains are susceptible to sulfamethoxazole $(16 \mu \mathrm{g})$ and resistant to amikacin $(16 \mu \mathrm{g})$.

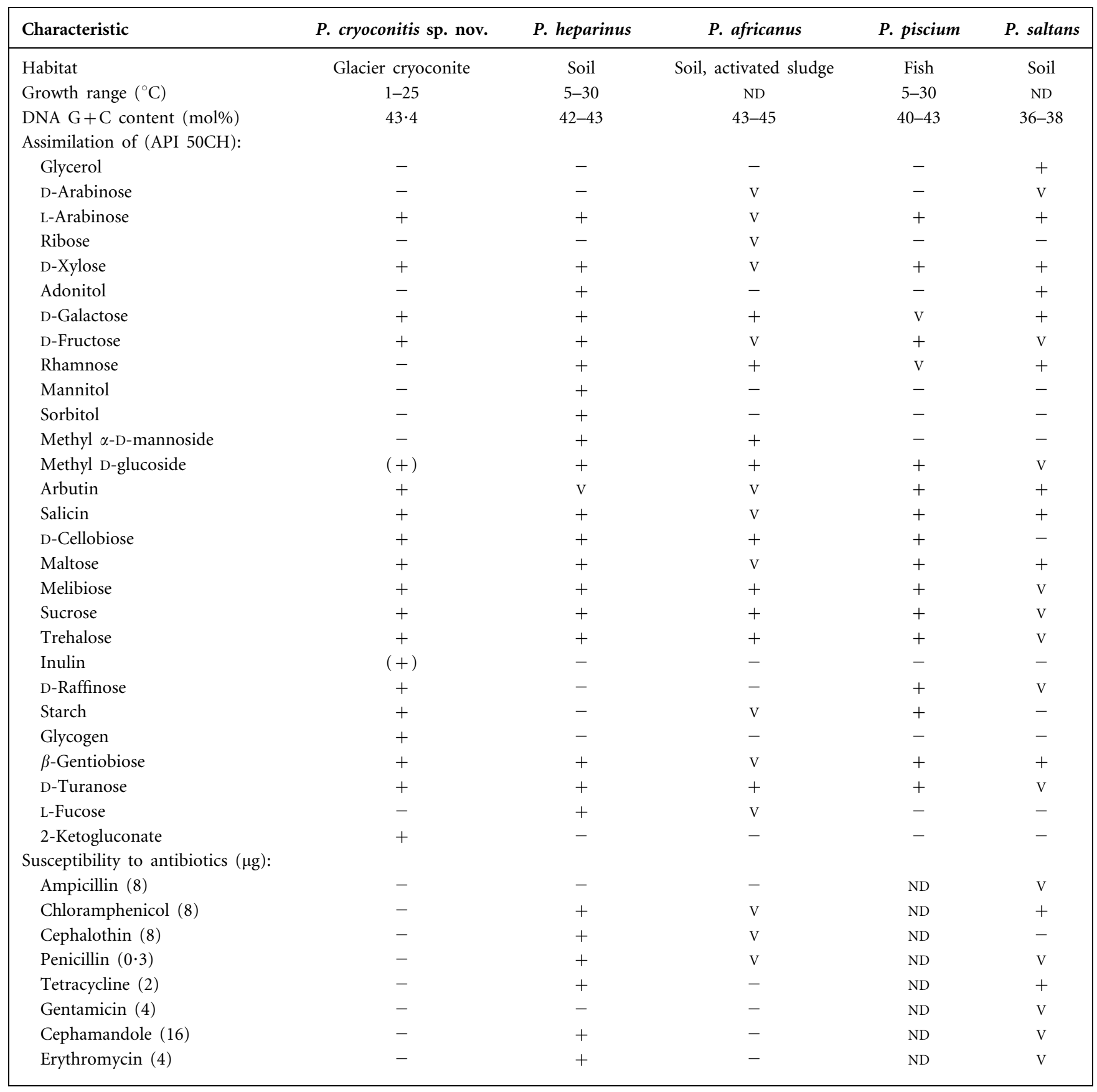

$10{ }^{\circ} \mathrm{C}$, a positive reaction was observed when transparent zones around the colonies were visible directly or detected after precipitation or staining of the undegraded substrate. In the case of $\beta$-lactamase activity, a positive reaction was indicated by growth in the presence of ampicillin.
Strain $A 37^{\mathrm{T}}$ isolated from alpine glacier cryoconite had all of the phenotypic characteristics of the genus Pedobacter (Steyn et al., 1998) (Table 1). The cells were Gram-negative, aerobic, rod-shaped $(0 \cdot 7-0 \cdot 9 \mu \mathrm{m}$ in diameter and $1 \cdot 5-3 \cdot 0 \mu \mathrm{m}$ long), non-spore-forming, non-flagellated and motile by 
gliding. On $\mathrm{R}_{2} \mathrm{~A}$ agar (composition given below), colonies were round, $2-4 \mathrm{~mm}$ in diameter, slightly convex, with entire margins, mucoid, motile by gliding and had a lightyellow non-fluorescent pigment. Activities of oxidase, catalase, DNase, amylase, $\beta$-glucosidase, $\beta$-galactosidase, protease (gelatin and casein) and $\beta$-lactamase were present, while activities of arginine dihydrolase, urease, esterase lipase $\left(\mathrm{C}_{4}\right)$ and tryptophan deaminase, nitrate reduction, $\mathrm{H}_{2} \mathrm{~S}$ production from thiosulfate, indole production and growth on MacConkey agar were not detected.

The strain assimilated the carbohydrates L-arabinose, Dxylose, D-galactose, D-glucose, D-fructose, D-mannose, arbutin, salicin, cellobiose, maltose, lactose, melibiose, sucrose, trehalose, D-raffinose, starch, glycogen, $\beta$-gentiobiose, D-turanose, gluconate and 2-ketogluconate. Methyl $\alpha$-Dglucoside and inulin were assimilated to a lesser extent. Assimilation of amygdalin and $\mathrm{N}$-acetylglucosamine was only noted after 8 days of incubation. The following carbohydrates were not assimilated: glycerol, erythritol, D-arabinose, ribose, L-xylose, adonitol, methyl $\beta$-xyloside, L-sorbose, rhamnose, dulcitol, inositol, mannitol, sorbitol, methyl $\alpha$-D-mannoside, melezitose, xylitol, D-lyxose, D-tagatose, Dfucose, D-arabitol, L-arabitol, 5-ketogluconate, phenylacetate, citrate, malate, adipate and caprate. Thus, strain $\mathrm{A} 37^{\mathrm{T}}$ can be distinguished from three Pedobacter species by its inability to assimilate rhamnose and from four Pedobacter species by its ability to assimilate glycogen, 2-ketogluconate and, to a lesser extent, inulin (Table 1).

The study of antibiotic susceptibility showed that strain $\mathrm{A} 37^{\mathrm{T}}$ was sensitive to sulfamethoxazole, which is a characteristic feature of Pedobacter species, and also to doxycycline and clindamycin. Resistance was observed to a wide range of antibiotics: penicillins (penicillin, ampicillin, mezlocillin, oxacillin, amoxicillin), cephalosporins (cephalothin, cephotaxim, cephazolin, cephtazidim, cephamandole), other $\beta$-lactams (aztreonam, imipenem), aminoglycosides (gentamicin, streptomycin), erythromycin, amikacin, chloramphenicol, tetracycline, fusidic acid and quinolones (ciprofloxacin, norfloxacin).

Analysis of fatty acid methyl esters was performed by GLC as described previously (Miller, 1982; Sasser, 1990). Dominant fatty acids $(51 \%)$ were iso-15:0 $2-\mathrm{OH}$ and $16: 1 \omega 7 c$. The presence of significant amounts of these two fatty acids is characteristic of all representatives of the family Sphingobacteriaceae (Steyn et al., 1998).

Genomic DNA extraction, PCR-mediated amplification of the 16S rDNA, purification of PCR products and electrophoresis of sequence reactions were done as described previously (Rainey et al., 1996). The $16 \mathrm{~S}$ rDNA sequence was aligned manually with published sequences from representatives of the Cytophaga-Flavobacterium-Bacteroides (CFB) group contained in the DSMZ database of $16 \mathrm{~S}$ rDNA sequences. The ae2 editor (Maidak et al., 1999) was used to align the $16 \mathrm{~S}$ rDNA sequence of strain $\mathrm{A} 37^{\mathrm{T}}$ against sequences of Pedobacter type strains available from public databases. Pairwise evolutionary distances were computed using the correction of Jukes \& Cantor (1969). The leastsquares distance method of De Soete (1983) was used in the construction of the phylogenetic dendrogram from distance matrices. Bootstrap analyses were done as described by Felsenstein (1993).

The almost-complete 16S rDNA sequence of strain $\mathrm{A} 37^{\mathrm{T}}$, consisting of $1495 \mathrm{nt}$, was compared with sequences of members of the CFB group. Members of the genus Pedobacter were the closest phylogenetic neighbours. Binary similarity values ranged between $97.9 \%$ (Pedobacter piscium DSM $11725^{\mathrm{T}}$ ) and $90 \cdot 3 \%$ (Pedobacter saltans DSM $12145^{\mathrm{T}}$ ). Similarly high values separated the type strains of Pedobacter heparinus (DSM 2366 ${ }^{\mathrm{T}}$ ) and Pedobacter africanus (DSM $\left.12126^{\mathrm{T}}\right)(97 \cdot 9 \%)$. Distance matrix analyses placed strain $\mathrm{A} 37^{\mathrm{T}}$ in a separate line of descent, showing no close relatedness to any of the type strains of Pedobacter (Fig. 1).

For DNA-DNA hybridization experiments, $P$. piscium DSM $11725^{\mathrm{T}}$ (showing $>97 \% 16 \mathrm{~S}$ rDNA sequence similarity) was used as a reference strain. DNA was isolated using a French pressure cell (Thermo Spectronic) and was purified by chromatography on hydroxyapatite according to the procedure of Cashion et al. (1977). DNA-DNA hybridization was carried out as described by De Ley et al. (1970), with the modification described by Huß et al. (1983) and Escara \& Hutton (1980), using a model 2600 spectrophotometer equipped with a Gilford model 2527-R thermoprogrammer and plotter. Renaturation rates were computed with the TRANSFER.BAS program (Jahnke, 1992). DNA from strain A $37^{\mathrm{T}}$ showed only $19 \cdot 7 \%$ genetic relatedness to the DNA of $P$. piscium. Based on generally accepted criteria of the definition of genomic species (Wayne et al., 1987), strain $\mathrm{A} 37^{\mathrm{T}}$ is assigned to a separate species.

The DNA G $+\mathrm{C}$ content for the genus Pedobacter ranges broadly from $36.9 \mathrm{~mol} \%$ (reported for $P$. saltans) to $44 \cdot 1 \mathrm{~mol} \%$ (reported for P. africanus) (Steyn et al., 1998). The $\mathrm{G}+\mathrm{C}$ content of the DNA of strain $\mathrm{A} 37^{\mathrm{T}}$ was

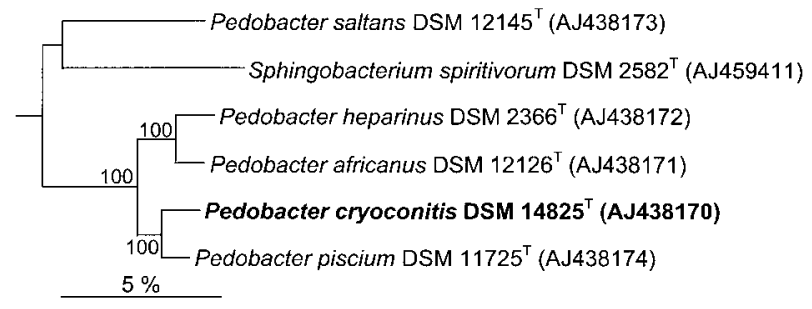

Fig. 1. Phylogenetic dendrogram obtained by distance-matrix analysis of 16S rDNA sequences showing the position of Pedobacter cryoconitis sp. nov. DSM $14825^{\top}$ among members of the genus Pedobacter. The sequence of Flavobacterium johnsoniae served as an outside reference. Bootstrap values $>95 \%$ are indicated at branch-points. Bar, 5 substitutions per 100 nucleotides. 
$43.4 \mathrm{~mol} \%$, determined after degradation of the DNA as described by Mesbah et al. (1989) and separation of the resulting nucleosides by HPLC as described by Tamaoka \& Komagata (1984).

Strain $\mathrm{A} 37^{\mathrm{T}}$ was routinely cultivated in the low-strength medium $\mathrm{R}_{2} \mathrm{~A}$, containing $0.05 \%$ yeast extract, $0.05 \%$ peptone, $0.05 \%$ Casamino acids, $0.05 \%$ glucose, $0.05 \%$ starch, $0.03 \%$ sodium pyruvate, $0.03 \% \mathrm{~K}_{2} \mathrm{HPO}_{4}$ and $0.005 \% \mathrm{MgSO}_{4}(\mathrm{pH} 7)$. This medium is suitable for the cultivation of micro-organisms from oligotrophic environmental habitats. Cultivation was done aerobically at 180 r.p.m. in 100-ml Erlenmeyer flasks containing $10 \mathrm{ml}$ $\mathrm{R}_{2} \mathrm{~A}$ medium with an initial cell density of $10^{8}$ c.f.u. $\mathrm{ml}^{-1}$ and three replicates per treatment, unless indicated otherwise.

The $\mathrm{pH}$ tolerance $(\mathrm{pH} 5-10)$ for growth was determined after $48 \mathrm{~h}$ at $20^{\circ} \mathrm{C}$. The $\mathrm{pH}$ range for growth was $5-8$, with optimum growth at $\mathrm{pH}$ 6-7.

The temperature tolerance for growth was examined at $1-30{ }^{\circ} \mathrm{C}$ in the absence and presence of oil hydrocarbons $[2 \mathrm{~g}$ diesel oil $\mathrm{l}^{-1}\left(85 \cdot 7 \% \mathrm{C}\right.$, density $\left.\left.820 \mathrm{~g} \mathrm{l}^{-1}\right)\right]$. Cell density in cultures was determined from cell protein concentrations. Protein was measured according to Bradford (1976) after disintegration of cells by boiling in $0 \cdot 1 \mathrm{M} \mathrm{NaOH}$ for $10 \mathrm{~min}$ (Chen \& Skidmore, 1987). There was no interference of diesel oil with this method. Optical density measurements were not possible in the presence of hydrocarbons due to the formation of cell aggregates. The bacterium exhibited the properties of a facultative psychrophile (Morita, 1975), showing a growth temperature range of $1-25^{\circ} \mathrm{C}$ and an optimum growth temperature of $20^{\circ} \mathrm{C}$ after $24 \mathrm{~h}$ cultivation. After $48 \mathrm{~h}$, comparable cell densities were detected over a cultivation temperature range of $10-25^{\circ} \mathrm{C}$. No growth occurred at $28^{\circ} \mathrm{C}$. Comparable cell densities were measured in cultures with and without diesel oil at all temperatures tested. Since the growth temperature range for strains of the genus Pedobacter is normally between 5 and $30^{\circ} \mathrm{C}$, and some strains of this genus may even grow at $37^{\circ} \mathrm{C}$ (Steyn et al., 1998), strain $\mathrm{A} 37^{\mathrm{T}}$ can be easily distinguished from other Pedobacter species by its inability to grow at $28^{\circ} \mathrm{C}$ and its ability to grow well at $1{ }^{\circ} \mathrm{C}$.

Another characteristic feature of strain $\mathrm{A} 37^{\mathrm{T}}$ is the ability to degrade oil hydrocarbons, which has not yet been described for other Pedobacter species. The effect of temperature on hydrocarbon biodegradation was evaluated at $1-25^{\circ} \mathrm{C}$ in the dark in $\mathrm{R}_{2} \mathrm{~A}$ medium containing $2 \mathrm{~g}$ diesel oil $\mathrm{l}^{-1}$. After 1-8 days, the residual hydrocarbon content was measured in inoculated and in sterile flasks as described previously (Margesin \& Schinner, 1997). Co-metabolic oil hydrocarbon biodegradation was calculated from the difference between hydrocarbon losses in the inoculated and sterile medium. Maximum biodegradation was observed at $15^{\circ} \mathrm{C}$; cultivation at this temperature resulted in decontamination of $53 \%$ of the diesel oil added $\left(2 \mathrm{~g} \mathrm{l}^{-1}\right)$ after 4 days. At lower temperatures, biodegradation was still remarkable (38-40\% at $5-10{ }^{\circ} \mathrm{C}, 26 \%$ at $\left.1{ }^{\circ} \mathrm{C}\right)$. After 8 days, comparable biodegradation was observed over a temperature range of $1-15^{\circ} \mathrm{C}$. Biodegradation was negligible at 20 and $25^{\circ} \mathrm{C}$.

The effect of hydrocarbon concentration on biodegradation was examined in the same medium supplemented with $1-20 \mathrm{~g}$ diesel oil $1^{-1}$ and incubated at $15^{\circ} \mathrm{C}$ for 4 days, using sterile controls for each concentration tested. Strain $\mathrm{A} 37^{\mathrm{T}}$ could grow in the presence of diesel oil concentrations up to $20 \mathrm{~g} \mathrm{l}^{-1}$; approximately $60 \%$ of initial concentrations in the range of $1-10 \mathrm{~g} \mathrm{l}^{-1}$ was degraded after 4 days at $15^{\circ} \mathrm{C}$.

The temperature tolerance for protease formation by strain $\mathrm{A} 37^{\mathrm{T}}$ was examined in nutrient broth supplemented with skimmed milk $\left(2 \mathrm{~g} \mathrm{l}^{-1}\right)$ at 180 r.p.m. and $1-25^{\circ} \mathrm{C}$. Proteolytic activity was measured by digestion of azocasein, as described by Margesin \& Schinner (1992a). Protease production was highest at a cultivation temperature of $15^{\circ} \mathrm{C}$, was approximately $50 \%$ lower at 10 and $20^{\circ} \mathrm{C}$ and was negligible at 1 and $25^{\circ} \mathrm{C}$. Strain $\mathrm{A} 37^{\mathrm{T}}$ also hydrolyses gelatin, a property that has been described for only one of six strains of $P$. africanus and not for $P$. heparinus, $P$. piscium or P. saltans (Steyn et al., 1998).

Among cold-adapted micro-organisms, obligate psychrophiles are distinguished from facultative psychrophiles because of differences in ecological distribution and biochemical adaptations (Russell, 1990). Even in permanently cold habitats, such as glacier cryoconite, at least $50 \%$ of the bacteria (Delille \& Perret, 1989) or even a greater portion (Herbert, 1986) is not obligately but facultatively psychrophilic, i.e. able to grow from $0{ }^{\circ} \mathrm{C}$ to temperatures above $20^{\circ} \mathrm{C}$, with an optimum growth temperature above $15^{\circ} \mathrm{C}$. Strain $\mathrm{A} 37^{\mathrm{T}}$ belongs to this latter group. Like many coldadapted micro-organisms, strain $\mathrm{A} 37^{\mathrm{T}}$ produces mucous polysaccharide capsules to protect the cells from environmental influences and to retain nutrients (Gounot, 1999). Although the strain was isolated from a non-contaminated environment, a remarkable oil hydrocarbon biodegradation activity was shown. This confirms that cold-adapted oil degraders are ubiquitous (Margesin \& Schinner, 2001).

Temperature had a significant effect on hydrocarbon biodegradation, protease production and growth of strain $\mathrm{A} 37^{\mathrm{T}}$. Despite high cell densities over a temperature range of $10-25^{\circ} \mathrm{C}$, a distinct optimum temperature of $15^{\circ} \mathrm{C}$ was noticed for both protease production and oil hydrocarbon biodegradation. The optimum temperature for substrate utilization by cold-adapted micro-organisms is usually significantly below the optimal growth temperature of the producing strains. Thermal inhibition of extracellular enzyme production (Margesin \& Schinner, 1992b) and, as demonstrated in this study, of hydrocarbon biodegradation is a common feature of these micro-organisms. The capacity of the isolate described to utilize both natural substrates (protein) and oil hydrocarbons at low temperature points to the ecological significance and biotechnological potential of the microbial community living in cryoconite.

In conclusion, the novel strain, $\mathrm{A} 37^{\mathrm{T}}$, can be distinguished 
easily from other Pedobacter species by its facultatively psychrophilic nature, i.e. inability to grow at $28^{\circ} \mathrm{C}$ and ability to grow at $1{ }^{\circ} \mathrm{C}$. Another characteristic feature of strain $\mathrm{A} 37^{\mathrm{T}}$ is the ability to degrade oil hydrocarbons, which has not yet been described for other Pedobacter species. Strain $\mathrm{A} 37^{\mathrm{T}}$ can also be distinguished from other Pedobacter species by its ability to assimilate glycogen and 2ketogluconate.

\section{Description of Pedobacter cryoconitis sp. nov.}

Pedobacter cryoconitis (cry.o.co.ni' tis. N.L. gen. n. cryoconitis from cryoconite).

On nutrient agar, colonies are light-yellow, round, convex, mucoid, with entire margins. Cells are rod-shaped $(0.7-0.9 \mu \mathrm{m}$ in diameter and $1.5-3.0 \mu \mathrm{m}$ long), Gramnegative, non-spore-forming, non-flagellated and motile by gliding. Oxidase, catalase, DNase, amylase, $\beta$-glucosidase, $\beta$-galactosidase, protease and $\beta$-lactamase are positive. Negative for activity of arginine dihydrolase, urease, lipase and tryptophan deaminase, nitrate reduction, $\mathrm{H}_{2} \mathrm{~S}$ production from thiosulfate, indole production and growth on MacConkey agar. Growth occurs between 1 and $25^{\circ} \mathrm{C}$ and $\mathrm{pH} 5-8$ in $\mathrm{R}_{2} \mathrm{~A}$ medium, with optimum growth at $20^{\circ} \mathrm{C}$ (facultatively psychrophilic) and $\mathrm{pH} 7$. No growth at $28^{\circ} \mathrm{C}$ or higher. The optimum temperature for biodegradation of diesel oil and for protease production is $15^{\circ} \mathrm{C}$. The strain assimilates L-arabinose, D-xylose, galactose, D-glucose, Dfructose, D-mannose, methyl $\alpha$-D-glucoside, arbutin, salicin, cellobiose, maltose, lactose, melibiose, sucrose, trehalose, inulin, D-raffinose, starch, glycogen, $\beta$-gentiobiose, Dturanose, gluconate and 2-ketogluconate. Dominant fatty acids $(51 \%)$ are iso-15:0 2-OH and $16: 1 \omega 7 c$. The $\mathrm{G}+\mathrm{C}$ content of the DNA of the type strain is $43.4 \mathrm{~mol} \%$.

The type strain, $\mathrm{A} 37^{\mathrm{T}}\left(=\right.$ DSM $14825^{\mathrm{T}}=\mathrm{LMG} 21415^{\mathrm{T}}$ ), was isolated from alpine glacier cryoconite on the Stubaier Glacier in the Tyrolean Alps, Austria.

\section{References}

Bej, A. K., Saul, D. \& Aislabie, J. (2000). Cold-tolerant alkanedegrading Rhodococcus species from Antarctica. Polar Biol 23, 100-105.

Bradford, M. M. (1976). A rapid and sensitive method for the quantitation of microgram quantities of protein utilizing the principle of protein-dye binding. Anal Biochem 72, 248-254.

Cashion, P., Holder-Franklin, M. A., McCully, J. \& Franklin, M. (1977). A rapid method for the base ratio determination of bacterial DNA. Anal Biochem 81, 461-466.

Chen, C.-Y. \& Skidmore, D. R. (1987). Langmuir adsorption isotherm for Sulfolobus acidocaldarius on coal particles. Biotechnol Lett 9, 191-194.

De Ley, J., Cattoir, H. \& Reynaerts, A. (1970). The quantitative measurement of DNA hybridization from renaturation rates. Eur J Biochem 12, 133-142.

Delille, D. \& Perret, E. (1989). Influence of temperature on the growth potential of southern polar marine bacteria. Microb Ecol 18, $117-123$.
De Soete, G. (1983). A least squares algorithm for fitting additive trees to proximity data. Psychometrika 48, 621-626.

Escara, J. F. \& Hutton, J. R. (1980). Thermal stability and renaturation of DNA in dimethyl sulfoxide solutions: acceleration of the renaturation rate. Biopolymers 19, 1315-1327.

Felsenstein, J. (1993). PHYLIP (Phylogenetic Inference Package) version 3.5c. Distributed by the author. Department of Genetics, University of Washington, Seattle, USA.

Gerday, C., Aittaleb, M., Bentahir, M. \& 11 other authors (2000). Cold-adapted enzymes: from fundamentals to biotechnology. Trends Biotechnol 18, 103-107.

Gounot, A. M. (1999). Microbial life in permanently cold soils. In Cold-Adapted Organisms, pp. 3-15. Edited by R. Margesin \& F. Schinner. Berlin: Springer.

Herbert, R. A. (1986). The ecology and physiology of psychrophilic microorganisms. In Microbes in Extreme Environments, pp. 1-23. Edited by R. A. Herbert \& G. A. Codd. London: Academic Press.

Huß, V. A. R., Festl, H. \& Schleifer, K. H. (1983). Studies on the spectrometric determination of DNA hybridization from renaturation rates. Syst Appl Microbiol 4, 184-192.

Huston, A. L., Krieger-Brockett, B. B. \& Deming, J. W. (2000). Remarkably low temperature optima for extracellular enzyme activity from Arctic bacteria and sea ice. Environ Microbiol 2, 383-388.

Jahnke, K.-D. (1992). Basic computer program for evaluation of spectroscopic DNA renaturation data from GILFORD System 2600 spectrometer on a PC/XT/AT type personal computer. J Microbiol Methods 15, 61-73.

Jukes, T. H. \& Cantor, C. R. (1969). Evolution of protein molecules. In Mammalian Protein Metabolism, vol. 3, pp. 21-132. Edited by H. N. Munro. New York: Academic Press.

Maidak, B. L., Cole, J. R., Parker, C. T., Jr \& 11 other authors (1999). A new version of the RDP (Ribosomal Database Project). Nucleic Acids Res 27, 171-173.

Margesin, R. \& Schinner, F. (1992a). A comparison of extracellular proteases from three psychrotrophic strains of Pseudomonas fluorescens. J Gen Appl Microbiol 38, 209-225.

Margesin, R. \& Schinner, F. (1992b). Extracellular protease production by psychrotrophic bacteria from glaciers. Int Biodeterior Biodegrad 29, 177-189.

Margesin, R. \& Schinner, F. (1997). Effect of temperature on oil degradation by a psychrotrophic yeast in liquid culture and in soil. FEMS Microbiol Ecol 24, 243-249.

Margesin, R. \& Schinner, F. (2001). Biodegradation and bioremediation of hydrocarbons in extreme environments. Appl Microbiol Biotechnol 56, 650-663.

Margesin, R., Feller, G., Gerday, C. \& Russell, N. J. (2002a). Coldadapted microorganisms: adaptation strategies and biotechnological potential. In The Encyclopedia of Environmental Microbiology, vol. 2, pp. 871-885. Edited by G. Bitton. New York: Wiley.

Margesin, R., Zacke, G. \& Schinner, F. (2002b). Characterization of heterotrophic microorganisms in alpine glacier cryoconite. Arct Antarct Alpine Res 34, 88-93.

Mesbah, M., Premachandran, U. \& Whitman, W. B. (1989). Precise measurement of the $\mathrm{G}+\mathrm{C}$ content of deoxyribonucleic acid by high-performance liquid chromatography. Int J Syst Bacteriol 39, 159-167.

Miller, L. T. (1982). Single derivatization method for routine analysis of bacterial whole-cell fatty acid methyl esters, including hydroxy acids. J Clin Microbiol 16, 584-586.

Morita, R. Y. (1975). Psychrophilic bacteria. Bacteriol Rev 39, 144-167. 
Morita, Y., Nakamura, T., Hasan, Q., Murakami, Y., Yokoyama, K. \& Tamiya, E. (1997). Cold-active enzymes from cold-adapted bacteria. J Am Oil Chem Soc 74, 441-444.

Rainey, F. A., Ward-Rainey, N., Kroppenstedt, R. M. \& Stackebrandt, E. (1996). The genus Nocardiopsis represents a phylogenetically coherent taxon and a distinct actinomycete lineage: proposal of Nocardiopsaceae fam. nov. Int J Syst Bacteriol 46, 1088-1092.

Russell, N. J. (1990). Cold adaptation of microorganisms. Philos Trans $R$ Soc London B Biol Sci 326, 595-608.

Sasser, M. (1990). Identification of bacteria by gas chromatography of cellular fatty acids. USFCC Newslett 20, 1-6.

Steyn, P. L., Segers, P., Vancanneyt, M., Sandra, P., Kersters, K. \& Joubert, J. J. (1998). Classification of heparinolytic bacteria into a new genus, Pedobacter, comprising four species: Pedobacter heparinus comb. nov., Pedobacter piscium comb. nov., Pedobacter africanus sp. nov. and Pedobacter saltans sp. nov. Proposal of the family Sphingobacteriaceae fam. nov. Int J Syst Bacteriol 48, 165-177.
Süßmuth, R., Eberspächer, J., Haag, R. \& Springer, W. (1987). Biochemisch-mikrobiologisches Praktikum. Stuttgart: Thieme.

Takeuchi, N., Kohshima, S. \& Seko, K. (2001). Structure, formation, and darkening process of albedo-reducing material (cryoconite) on a Himalayan glacier: a granular algal mat growing on the glacier. Arct Antarct Alpine Res 33, 115-122.

Tamaoka, J. \& Komagata, K. (1984). Determination of DNA base composition by reversed-phase high-performance liquid chromatography. FEMS Microbiol Lett 25, 125-128.

Wayne, L. G., Brenner, D. J., Colwell, R. R. \& 9 other authors (1987). Report of the ad hoc committee on reconciliation of approaches to bacterial systematics. Int $J$ Syst Bacteriol 37, 463-464.

Yumoto, I., Nakamura, A., Iwata, H., Kojima, K., Kusumoto, K., Nodasaka, Y. \& Matsuyama, H. (2002). Dietzia psychralcaliphila sp. nov., a novel, facultatively psychrophilic alkaliphile that grows on hydrocarbons. Int J Syst Evol Microbiol 52, 85-90. 